\title{
The truth in complexes: perspectives on ion channel signaling nexuses in the nervous system
}

\author{
Leigh A. Swayne ${ }^{1,2,3}{ }^{*}$, Christophe Altier ${ }^{4}$ and Gerald W. Zamponi ${ }^{4}$ \\ ${ }^{1}$ Island Medical Program, Division of Medical Sciences, University of Victoria, Victoria, BC, Canada \\ 2 Department of Biology, University of Victoria, Victoria, BC, Canada \\ ${ }^{3}$ Department of Cellular and Physiological Sciences, University of British Columbia, Vancouver, BC, Canada \\ ${ }^{4}$ Department of Physiology and Pharmacology, University of Calgary, Calgary, AB, Canada \\ *Correspondence: Iswayne@uvic.ca \\ Edited and reviewed by: \\ Egidio D'Angelo, University of Pavia, Italy
}

Keywords: interactome, ion channels, signaling networks, protein-protein interactions, protein-lipid interactions

\section{ION CHANNELS AS SIGNALING NEXUSES}

Ion channels are complex hetero-oligomeric structures characterized by large, dynamic interaction networks, or "interactomes." In addition to directing channel localization, density and ion fluxes, these complexes facilitate downstream signaling events. Moreover, pathological modulation of these networks contributes to neurological dysfunction. Our contributors to this Research Topic, "The truth in complexes: why unraveling ion channel multiprotein signaling nexuses is critical for understanding the function of the nervous system" have considered interactomes from the perspective of the ion channel, from that of its intracellular protein modulators, and even from the point of view of lipid modulators. Together these diverse perspectives spin an intricate web of ion channel regulation in the nervous system.

\section{MAJOR HUB: THE N-methyl-D-ASPARTATE RECEPTOR (NMDAR)}

Described by Fan et al. (2014) as a "multifunctional machine," the NMDAR interacts with a staggering number of proteins to shape synaptic plasticity, psychiatric disorders and ischemic neuronal damage. Notably, the authors outline arguably the most exciting example of interactome-based basic science leading to improved health outcomes: Tat-NR2B9c (also called NA-1). This cellpermeable peptide targets a specific NMDAR interaction, reducing ischemic brain damage in rodents, primates and humans (Sun et al., 2008; Cook et al., 2012; Hill et al., 2012). Li et al. (2014) similarly highlights interactions between several ligandgated channels, including the NMDAR with other receptors and intracellular proteins, again focusing on these interactions as potential therapeutic targets for neuroprotection.

\section{NOVEL NODES}

Several other contributions shed light on the new insights into the function and composition of interactomes of various voltagegated channels, regulated leak channels, and so called large pore channels.

\section{VOLTAGE-GATED CHANNELS}

Traditionally viewed as auxiliary subunits, $\mathrm{K}^{+}$channel regulatory proteins are growing in complexity in terms of function and type. Known to regulate activation and trafficking of muscarinic receptor-activated Kir3 channels, Zylbergold et al. (2014) provide evidence for an additional role of $\mathrm{G} \beta \gamma$ subunits in Kir3 channel stability. Nagi and Pineyro (2014) focus specifically on opioid receptor signaling in the regulation of these channels. Jerng and Pfaffinger (2014) describe regulation of another $\mathrm{K}^{+}$current, sub-threshold A-type (Kv4), by the so-called auxiliary subunits, dipeptidyl peptidase-like proteins (DPLPs) and Kv4 channel interacting proteins (KChIPs). While these were amongst the first identified interactors (e.g., for KChiP An et al., 2000), subsequent studies have significantly expanded the network. With respect to DPLPs and KChIPs, further study has also shed new light on their molecular diversity via alternative splicing as well as their roles in regulating several other channel types, such as voltage-gated $\mathrm{Ca}^{2+}$ channels and NMDARs. Connecting $\mathrm{K}^{+}$channels with voltage-gated $\mathrm{Ca}^{2+}$ channels, Engbers et al. (2013) review how channel-channel interactions between intermediate conductance $\mathrm{Ca}^{2+}$-activated $\mathrm{K}^{+}$channels (IKCa) and low voltage-activated $\mathrm{Ca}^{2+}$ channels (Cav3) functionally interact with other conductances to regulate signal processing in the cerebellum.

\section{$\mathrm{Na}^{+}$LEAK CHANNEL, NALCN}

Elusive until recently, understanding of this regulated leak channel whose loss in mice is lethal (Lu et al., 2007), has greatly expanded by virtue of key insights into its interactome. CochetBissuel et al. (2014) detail its ever-expanding list of interacting proteins, such as the M3 muscarinic receptor (Swayne et al., 2009). The authors highlight the involvement of the NALCN interactome in a number of disorders in the nervous system ranging from autism spectrum disorder (ASD) and schizophrenia to epilepsy and Alzheimer's disease.

\section{PANNEXIN 1 (PANX1)}

Permeable to ions and small metabolites like ATP, Panx1 channels gained early notoriety as "death pores" in ischemic stroke and seizure (Thompson et al., 2006, 2008; Weilinger et al., 2012). Highly expressed in neonatal brain (Ray et al., 2005; Vogt et al., 2005), Panx1 also positively regulates proliferation and differentiation, and negatively regulates neurite outgrowth in developing neurons (Wicki-Stordeur et al., 2012; Wicki-Stordeur 
and Swayne, 2013). Wicki-Stordeur and Swayne (2014) reviewed the growing Panx1 interactome to shed clues on the signaling pathways in which Panx1 might be involved, highlighting roles in cytoskeletal remodeling and inflammation.

\section{MULTI-TASKING INTRACELLULAR MODULATORS}

A number of contributions underscore the capacity of "promiscuous" intracellular proteins to modulate a variety of ion channels and receptors through physical interaction. Reviewed by Donnelier and Braun (2014), cysteine string protein (CSP) is a resident pre-synaptic vesicle molecular chaperone targeting ion channels and vesicle-trafficking proteins. Not surprisingly, loss of, or mutation in CSP leads to synaptic dysfunction and neurodegeneration in a variety of systems (e.g., Zinsmaier et al., 1994; Fernandez-Chacon et al., 2004; Noskova et al., 2011). The sigma-1 receptor, reviewed by Pabba (2013), is an intracellular transmembrane protein that also acts in a chaperone-like way, modulating plasma membrane localized voltage- and ligand-gated channels with diverse neurophysiological and neuropathological implications. Harraz and Altier (2014) further link intracellular proteins to the regulation of plasma membrane channels, reviewing Stromal Interaction Molecule 1 (STIM1) in store-operated $\mathrm{Ca}^{2+}$ entry. They describe foundational work implicating STIM1 as the $\mathrm{Ca}^{2+}$ sensor in this process critical for maintaining neurotransmission. Further they outline key physical interactions between STIM1 with $\mathrm{Ca}^{2+}$-release activated channels and voltage-gated $\mathrm{Ca}^{2+}$ channels that coordinate the activation and inhibition of these types of channels, respectively. Finally, two papers by Wilson et al. (2014a,b) focus on another intracellular multifunctional/multi-interactome protein, collapsin response mediator protein 2 (Crmp2). Best known as a microtubule stabilizer, Crmp2 is regulated in a context specific way by multiple kinases, and in turn, positively regulates both ligand- and voltage-gated $\mathrm{Ca}^{2+}$ channels.

\section{NEW FRONTIERS: TOWARD MORE COMPREHENSIVE MACROMOLECULAR NETWORKS}

Adding further complexity to ion channel networks is consideration of lipid membrane composition and lipid second messengers. In the sole lipidome-oriented contribution, Raboune et al. (2014) identify novel $\mathrm{N}$-acyl amides regulating transient receptor potential vanilloid (TRPV) channels in the context of inflammatory pain. The future understanding of ion channel interactomes will undoubtedly include both proteome and lipidome components as technological advances in lipidomic research (Bou Khalil et al., 2010) become mainstream.

\section{FINAL PERSPECTIVES: INTERACTOMES TO BEDSIDE}

While daunting, elucidating these macromolecular intricacies has a translational silver lining: while difficult to identify and unravel, the myriad interaction loci revealed by studying these interactions present unique opportunities for discrete, and potentially safer therapeutic intervention. For example, selective blockade at key interaction loci with cell-permeable peptides now provides an infinite number of ways in which interactomes can be discretely modulated to improve health outcomes.

\section{REFERENCES}

An, W. F., Bowlby, M. R., Betty, M., Cao, J., Ling, H. P., Mendoza, G., et al. (2000) Modulation of A-type potassium channels by a family of calcium sensors. Nature 403, 553-556. doi: 10.1038/35000592

Bou Khalil, M., Hou, W., Zhou, H., Elisma, F., Swayne, L. A., Blanchard, A. P., et al. (2010). Lipidomics era: accomplishments and challenges. Mass Spectrom. Rev. 29, 877-929. doi: 10.1002/mas.20294

Cochet-Bissuel, M., Lory, P., and Monteil, A. (2014). The sodium leak channel, NALCN, in health and disease. Front. Cell. Neurosci. 8:132. doi: 10.3389/fncel.2014.00132

Cook, D. J., Teves, L., and Tymianski, M. (2012). Treatment of stroke with a PSD95 inhibitor in the gyrencephalic primate brain. Nature 483, 213-217. doi: 10.1038 /nature 10841

Donnelier, J., and Braun, J. E. (2014). CSPalpha-chaperoning presynaptic proteins. Front. Cell. Neurosci. 8:116. doi: 10.3389/fncel.2014.00116

Engbers, J. D., Anderson, D., Zamponi, G. W., and Turner, R. W. (2013). Signal processing by T-type calcium channel interactions in the cerebellum. Front. Cell. Neurosci. 7:230. doi: 10.3389/fncel.2013.00230

Fan, X., Jin, W. Y., and Wang, Y. T. (2014). The NMDA receptor complex: a multifunctional machine at the glutamatergic synapse. Front. Cell. Neurosci. 8:160. doi: 10.3389/fncel.2014.00160

Fernandez-Chacon, R., Wolfel, M., Nishimune, H., Tabares, L., Schmitz, F., Castellano-Munoz, M., et al. (2004). The synaptic vesicle protein CSP alpha prevents presynaptic degeneration. Neuron 42, 237-251. doi: 10.1016/S08966273(04)00190-4

Harraz, O. F., and Altier, C. (2014). STIM1-mediated bidirectional regulation of $\mathrm{Ca}(2+)$ entry through voltage-gated calcium channels (VGCC) and calcium-release activated channels (CRAC). Front. Cell. Neurosci. 8:43. doi: 10.3389/fncel.2014.00043

Hill, M. D., Martin, R. H., Mikulis, D., Wong, J. H., Silver, F. L., Terbrugge, K. G., et al. (2012). Safety and efficacy of NA-1 in patients with iatrogenic stroke after endovascular aneurysm repair (ENACT): a phase 2, randomised, doubleblind, placebo-controlled trial. Lancet Neurol. 11, 942-950. doi: 10.1016/S14744422(12)70225-9

Jerng, H. H., and Pfaffinger, P. J. (2014). Modulatory mechanisms and multiple functions of somatodendritic A-type $\mathrm{K}(+)$ channel auxiliary subunits. Front. Cell. Neurosci. 8:82. doi: 10.3389/fncel.2014.00082

Li, S., Wong, A. H., and Liu, F. (2014). Ligand-gated ion channel interacting proteins and their role in neuroprotection. Front. Cell. Neurosci. 8:125. doi: 10.3389/fncel.2014.00125

Lu, B., Su, Y., Das, S., Liu, J., Xia, J., and Ren, D. (2007). The neuronal channel NALCN contributes resting sodium permeability and is required for normal respiratory rhythm. Cell 129, 371-383. doi: 10.1016/j.cell.2007.02.041

Nagi, K., and Pineyro, G. (2014). Kir3 channel signaling complexes: focus on opioid receptor signaling. Front. Cell. Neurosci. 8:186. doi: 10.3389/fncel.2014.00186

Noskova, L., Stranecky, V., Hartmannova, H., Pristoupilova, A., Baresova, V., Ivanek, R., et al. (2011). Mutations in DNAJC5, encoding cysteine-string protein alpha, cause autosomal-dominant adult-onset neuronal ceroid lipofuscinosis. Am. J. Hum. Genet. 89, 241-252. doi: 10.1016/j.ajhg.2011.07.003

Pabba, M. (2013). The essential roles of protein-protein interaction in sigma-1 receptor functions. Front. Cell. Neurosci. 7:50. doi: 10.3389/fncel.2013.00050

Raboune, S., Stuart, J. M., Leishman, E., Takacs, S. M., Rhodes, B., Basnet, A., et al. (2014). Novel endogenous $\mathrm{N}$-acyl amides activate TRPV1-4 receptors, BV-2 microglia, and are regulated in brain in an acute model of inflammation. Front. Cell. Neurosci. 8:195. doi: 10.3389/fncel.2014.00195

Ray, A., Zoidl, G., Weickert, S., Wahle, P., and Dermietzel, R. (2005). Site-specific and developmental expression of pannexin 1 in the mouse nervous system. Eur. J. Neurosci. 21, 3277-3290. doi: 10.1111/j.1460-9568.2005.04139.x

Sun, H. S., Doucette, T. A., Liu, Y., Fang, Y., Teves, L., Aarts, M., et al. (2008). Effectiveness of PSD95 inhibitors in permanent and transient focal ischemia in the rat. Stroke 39, 2544-2553. doi: 10.1161/STROKEAHA.107.506048

Swayne, L. A., Mezghrani, A., Varrault, A., Chemin, J., Bertrand, G., Dalle, S., et al. (2009). The NALCN ion channel is activated by M3 muscarinic receptors in a pancreatic beta-cell line. EMBO Rep. 10, 873-880. doi: 10.1038/embor. 2009.125

Thompson, R. J., Jackson, M. F., Olah, M. E., Rungta, R. L., Hines, D. J., Beazely, M. A., et al. (2008). Activation of pannexin-1 hemichannels augments aberrant bursting in the hippocampus. Science 322, 1555-1559. doi: 10.1126/science.1165209 
Thompson, R. J., Zhou, N., and Macvicar, B. A. (2006). Ischemia opens neuronal gap junction hemichannels. Science 312, 924-927. doi: 10.1126/science. 1126241

Vogt, A., Hormuzdi, S. G., and Monyer, H. (2005). Pannexin1 and Pannexin2 expression in the developing and mature rat brain. Brain Res. Mol. Brain Res. 141, 113-120. doi: 10.1016/j.molbrainres.2005.08.002

Weilinger, N. L., Tang, P. L., and Thompson, R. J. (2012). Anoxia-induced NMDA receptor activation opens pannexin channels via Src family kinases. J. Neurosci. 32, 12579-12588. doi: 10.1523/JNEUROSCI.1267-12.2012

Wicki-Stordeur, L. E., Dzugalo, A. D., Swansburg, R. M., Suits, J. M., and Swayne, L. A. (2012). Pannexin 1 regulates postnatal neural stem and progenitor cell proliferation. Neural Dev. 7, 11. doi: 10.1186/1749-8104-7-11

Wicki-Stordeur, L. E., and Swayne, L. A. (2013). Panx1 regulates neural stem and progenitor cell behaviours associated with cytoskeletal dynamics and interacts with multiple cytoskeletal elements. Cell Commun. Signal. 11, 62. doi: 10.1186/1478-811X-11-62

Wicki-Stordeur, L. E., and Swayne, L. A. (2014). The emerging Pannexin 1 signalome: a new nexus revealed? Front. Cell. Neurosci. 7:287. doi: $10.3389 /$ fncel.2013.00287

Wilson, S. M., Ki Yeon, S., Yang, X. F., Park, K. D., and Khanna, R. (2014a). Differential regulation of collapsin response mediator protein 2 (CRMP2) phosphorylation by GSK3ss and CDK5 following traumatic brain injury. Front. Cell. Neurosci. 8:135. doi: 10.3389/fncel.2014.00135

Wilson, S. M., Moutal, A., Melemedjian, O. K., Wang, Y., Ju, W., FrancoisMoutal, L., et al. (2014b). The functionalized amino acid (S)-Lacosamide subverts CRMP2-mediated tubulin polymerization to prevent constitutive and activity-dependent increase in neurite outgrowth. Front. Cell. Neurosci. 8:196. doi: 10.3389/fncel.2014.00196

Zinsmaier, K. E., Eberle, K. K., Buchner, E., Walter, N., and Benzer, S. (1994). Paralysis and early death in cysteine string protein mutants of Drosophila Science 263, 977-980.

Zylbergold, P., Sleno, R., Khan, S. M., Jacobi, A. M., Belhke, M. A., and Hebert, T. E. (2014). Kir3 channel ontogeny - the role of Gbetagamma subunits in channel assembly and trafficking. Front. Cell. Neurosci. 8:108. doi: $10.3389 /$ fncel.2014.00108

Conflict of Interest Statement: The authors declare that the research was conducted in the absence of any commercial or financial relationships that could be construed as a potential conflict of interest.

Received: 26 September 2014; accepted: 10 November 2014; published online: 26 November 2014.

Citation: Swayne LA, Altier C and Zamponi GW (2014) The truth in complexes: perspectives on ion channel signaling nexuses in the nervous system. Front. Cell. Neurosci. 8:406. doi: $10.3389 /$ fncel.2014.00406

This article was submitted to the journal Frontiers in Cellular Neuroscience.

Copyright (c) 2014 Swayne, Altier and Zamponi. This is an open-access article distributed under the terms of the Creative Commons Attribution License (CC BY). The use, distribution or reproduction in other forums is permitted, provided the original author(s) or licensor are credited and that the original publication in this journal is cited, in accordance with accepted academic practice. No use, distribution or reproduction is permitted which does not comply with these terms. 